\title{
Extracorporeal membrane oxygenation offers long-term survival in childhood leukemia and acute respiratory failure
}

\author{
Gerard Cortina, Nikolaus Neu, Gabriele Kropshofer, Bernhard Meister, Uwe Klingkowski and Roman Crazzolara*
}

Keywords: Extracorporeal membrane oxygenation, Childhood leukemia, Acute respiratory failure

\section{Dear Editor:}

Survival for childhood cancer has dramatically improved, particularly for acute lymphoblastic leukemia, reaching over $90 \%$ overall survival in industrialized countries [1]. However, some patients may encounter severe adverse events, limiting this high success rate. ARF is one of the most serious complications and is associated with high mortality if conventional therapy fails [2]. Escalation to ECMO has rarely been used in patients with malignancy due to its limited success rates and higher risk for infectious and bleeding complications [3-5].

We report on a single centre experience of ECMO on patients with childhood leukemia and ARF. This retrospective study was approved by the local research ethics committee. Nine patients with childhood leukemia received ECMO in induction treatment (8/9 at first remission, $1 / 9$ at second remission) between January 2004 and June 2017. Details on these patients are provided in Table 1. ARF resulted from pulmonary infections (two patients with Candida albicans, one patient with Aspergillus terreus, four patients with no organisms identified) and pulmonary non-infectious complications (one patient with transfusion-related acute lung injury and one patient with leukemic infiltration). Median duration of mechanical ventilation before ECMO was 3 days (range 0.4-14). The median duration of ECMO support was 14 days (range 2-24). Five (56\%) patients survived ECMO und four (44\%) survived to hospital discharge. When compared to survivors, non-survivors had a significantly higher vasoactive inotrope score (VIS) at ECMO initiation ( 85 vs. $11 ; p=0.032$ ), including two patients requiring veno-arterial cannulation. Time on ECMO support was shorter ( 5 vs. 15 days; $p=0.032$ ) in non-survivors and was stopped because of multiorgan failure (22\%), intracranial bleeding (11\%) and progressive leukemia (11\%). One patient (11\%) recovered from hematopoietic stem cell transplantation performed on ECMO, but died two months later of septic shock. Moreover, non-survivors had significantly lower platelet count on ECMO $\left(30 \times 10^{3} / \mu \mathrm{L}\right.$ vs $\left.98 \times 10^{3} / \mu \mathrm{L} ; p=0.041\right)$. Eight $(89 \%)$ patients received chemotherapy in the four weeks prior to and five (56\%) were neutropenic at ECMO cannulation. Neutropenic patients did not have higher mortality compared to those without neutropenia (3/5 vs $2 / 4)$.

All four survivors are in complete oncologic remission at a median follow-up of 8.4 years (range 1.8-13.1), are restored to full health, and are all engaged to full-time study or work. Our data is limited by a small sample size and by its retrospective analysis. Nevertheless, it indicates that ECMO provides an effective rescue therapy in childhood leukemic patients with ARF.

* Correspondence: roman.crazzolara@i-med.ac.at

Department of Pediatrics, Medical University of Innsbruck, Anichstrasse 35,

A-6020 Innsbruck, Austria

(c) The Author(s). 2018 Open Access This article is distributed under the terms of the Creative Commons Attribution 4.0 International License (http://creativecommons.org/licenses/by/4.0/), which permits unrestricted use, distribution, and

reproduction in any medium, provided you give appropriate credit to the original author(s) and the source, provide a link to the Creative Commons license, and indicate if changes were made. The Creative Commons Public Domain Dedication waiver (http://creativecommons.org/publicdomain/zero/1.0/) applies to the data made available in this article, unless otherwise stated. 
Table 1 Clinical characteristics and demographics of patients on ECMO

\begin{tabular}{|c|c|c|c|c|c|c|}
\hline Clinical characteristics & $\mathrm{N}$ & Demographics & All & Survivors & Non-survivors & $p$-value \\
\hline Diagnosis & & Age (years) & $14(1-18)$ & $9(4-16)$ & $16(1-18)$ & 0.286 \\
\hline ALL & 5 & Weight (kg) & $47(7-74)$ & $26(12-50)$ & $56(7-74)$ & 0.286 \\
\hline AML & 3 & Pre ECMO & & & & \\
\hline JMML & 1 & $\mathrm{pH}$ & $7.2(7.0-7.6)$ & $7.3(7.0-7.6)$ & $7.2(7.0-7.4)$ & 0.413 \\
\hline Reason for ARF & & Lactate (mg/dL) & $17(7-68)$ & $17(7-24)$ & $17(8-68)$ & 0.556 \\
\hline Fungal infection & 3 & $\mathrm{pO} 2 / \mathrm{FiO} 2$ & $47(32-67)$ & $66(32-67)$ & $44(34-50)$ & 0.286 \\
\hline Pulmonary infection ${ }^{a}$ & 4 & VIS score & $45(5-160)$ & $11(5-45)$ & $85(22-160)$ & 0.032 \\
\hline TRALI & 1 & Platelet count $\left(\times 10^{3} / \mu \mathrm{L}\right)$ & $27(14-214)$ & $145(26-214)$ & $27(14-53)$ & 0.111 \\
\hline Leukemic infiltration & 1 & Ventilation days & $3(0.4-14)$ & $4.5(1-13)$ & $2(0.4-12)$ & 0.556 \\
\hline Causes of death on ECMO & & During ECMO & & & & \\
\hline Intracranial hemorrhage & 1 & Platelet count $\left(\times 10^{3} / \mu \mathrm{L}\right)$ & $35(19-106)$ & $98(22-106)$ & $30(19-48)$ & 0.041 \\
\hline Multiorgan failure & 2 & Platelets transfusions / day & $2.2(0.2-3.8)$ & $0.5(0.2-2.2)$ & $3.3(1.7-4.7)$ & 0.111 \\
\hline Leukemic infiltration & 1 & W Cannulation & 7 & 5 & 2 & \\
\hline Outcome on ECMO & & VA Cannulation & 2 & 0 & 2 & \\
\hline Survived on ECMO & 5 & Major bleeding & 4 & 0 & 4 & \\
\hline Discharged from hospital & 4 & Need for CRRT & 3 & 0 & 3 & \\
\hline Survived long-term & 4 & ECMO Duration (days) & $14(2-24)$ & $15(9-24)$ & $5(2-17)$ & 0.032 \\
\hline
\end{tabular}

ano organism detected

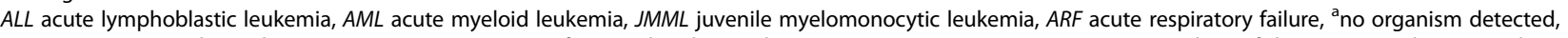
$E C M O$ extracorporeal membrane oxygenation, TRALI transfusion-related acute lung injury, VIS vasoactive inotrope score $=$ dose of dopamine ( $\mu \mathrm{g} / \mathrm{kg} / \mathrm{min})+\mathrm{dose}$ of dobutamine $(\mu \mathrm{g} / \mathrm{kg} / \mathrm{min})+100 \times$ dose of adrenaline $(\mu \mathrm{g} / \mathrm{kg} / \mathrm{min})+100 \times$ dose of noradrenaline $(\mu \mathrm{g} / \mathrm{kg} / \mathrm{min})+10 \times \mathrm{milrinone}$ dose $(\mu \mathrm{g} / \mathrm{kg} / \mathrm{min})+10,000 \times$ dose of vasopressin (U/kg/min), $W$ veno-venous, $V A$ veno-arterial, CRRT continuous renal replacement therapy

\section{Abbreviations}

ARF: Acute respiratory failure; ECMO: Extracorporeal membrane oxygenation

\section{Availability of data and materials}

The datasets used and analyzed during the current study are available from the corresponding author on reasonable request.

\section{Authors' contributions}

GC, GK and RC conceived the study and collected the data. GC and RC performed the statistical analyses. GC and RC interpreted the data and wrote the first draft of the manuscript. All authors critically reviewed and edited the manuscript and all authors read and approved the final version.

\section{Ethics approval and consent to participate}

The study was conducted in accordance with Good Clinical Practice (Declaration of Helsinki 2002) and was approved by the Ethics Committee of the Medical University of Innsbruck (Reference Number 34266 A). Consent for patient participation was waived.
Received: 29 March 2018 Accepted: 25 July 2018

Published online: 22 September 2018

\section{References}

1. Gatta G, Botta L, Rossi S, Aareleid T, Bielska-Lasota M, Clavel J, Dimitrova N, Jakab Z, Kaatsch P, Lacour B, et al. Childhood cancer survival in Europe 1999-2007: results of EUROCARE-5--a population-based study. Lancet Oncol. 2014;15(1):35-47.

2. Azoulay $E$, Lemiale $V$, Mokart $D$, Pene F, Kouatchet A, Perez P, Vincent F Mayaux J, Benoit D, Bruneel $F$, et al. Acute respiratory distress syndrome in patients with malignancies. Intensive Care Med. 2014;40(8):1106-14.

3. Gow KW, Heiss KF, Wulkan ML, Katzenstein HM, Rosenberg ES, Heard ML, Rycus PT, Fortenberry JD. Extracorporeal life support for support of children with malignancy and respiratory or cardiac failure: the extracorporeal life support experience. Crit Care Med. 2009;37(4):1308-16.

4. Smith $\mathrm{S}$, Butt W, Best D, MacLaren G. Long-term survival after extracorporeal life support in children with neutropenic sepsis. Intensive Care Med. 2016;42(5):942-3.

5. Di Nardo M, Locatelli F, Palmer K, Amodeo A, Lorusso R, Belliato M, Cecchetti C, Perrotta D, Picardo S, Bertaina A, et al. Extracorporeal membrane oxygenation in pediatric recipients of hematopoietic stem cell transplantation: an updated analysis of the extracorporeal life support organization experience. Intensive Care Med. 2014;40(5):754-6.

\section{Consent for publication}

No consent for publication was needed.

\section{Competing interests}

The authors declare that they have no competing interests.

\section{Publisher's Note}

Springer Nature remains neutral with regard to jurisdictional claims in published maps and institutional affiliations. 